\title{
CORRELATION OF COGNITIVE ABILITIES LEVEL, AGE AND RANKS IN JUDO
}

\author{
Stanislav Kraček, Petra Pačesová, Pavel Šmela, Miloš Štefanovský \\ Department of Sport Educology and Sport Humanities, Faculty of Physical Education and Sport, \\ Comenius University in Bratislava, Slovakia
}

\begin{abstract}
SUMMARY: The aim of this paper is to ascertain the correlation between selected cognitive abilities, age and performance of judokas according to ranking. The study group consisted of judokas in the age group $18 \pm 2.4$ years. The Stroop Color-Word Test - Victoria Version (VST) was the instrument used to determine the level of cognitive abilities. The data obtained were measured by the Pearson Correlation (r) correlation test. The results of the study show an associative relationship of indirect correlation $(p<0.01)$ between age and all of the three categories of the Stroop test. This is an indirect correlation, so the higher the age, the lower the time (better performance) of the probands in the Stroop test. There was no statistically significant correlation between performance in the categories of the Stroop test and rankings. The outcomes show that the level of selected cognitive abilities depends on age, but the level of the selected cognitive abilities does not affect the ranking of the judokas.
\end{abstract}

Key words: cognitive abilities, stroop test, judo, ranking

DOI 10.1515/afepuc-2016-0009

(C) Acta Facultatis Educationis Physicae Universitatis Comenianae 


\section{Introduction}

Athletic performance depends on various components, such as physical, technical, tactical and psychological preparation. Mental capabilities, one of which is attention, are directly associated with cognitive abilities (Sánchez et al. 2013).

Judo is an Olympic combat sport involving direct contact between two opponents using attack and defence techniques and tactics waged in battle in either an upright position or lying down. The objective is to gain technical advantage and higher scoring according to the rules of the competition (Štefanovský 2015). The goal is for the all-round development of the functional, energy, psychosomatic, motor, and coordination skills of the child (Moravec et al. 2007). Judokas have need to react to different factors as to pay attention to referee notes during wrestling, coach's verbal comments, perception of the environment identify an opponent's wrestling style, his technical, predict tactical and physical fitness level, anticipate their opponent acts or pay attention additional stimuli such as a time-keeping table (Zubitashvili \& Mayashvili 2012; Mihailescu \& Sava 2013).

Attention problems are caused by factors that are external or internal nature. Among external factors, athletes can be distracted by some internal mental states, thoughts, concerns (Mihailescu \& Sava 2013).

During our study, we were interested in the correlation between the level of chosen cognitive abilities and the judo rankings among adolescents. Judo is namely very dynamic sport and success in competition can depend on the decision in seconds (Mihailescu \& Sava 2013). Mustafa (2009) also wrote about the relationship between judo competition results and several variables, such as attention and cognitive tempo.

The Stroop test looks primarily at a person's attention such as centring attention on certain objects. It allows for optimal reception of information and other objects, while other types of information are excluded. Selective attention is very important, specifically selective attention in vision. Selective attention is active, deliberate and voluntary. It holds a person in an activity that may be difficult and relatively exhausting. It is elicited and guided directly by the person, by his voluntary processes. It is associated with the idea of the direction, course and goal of the activity (Gregor 2013; Stenberg, Sternberg \& Mio 2012).

In addition to selective attention, the Stroop test also involves implicit memory. It relates to the knowledge a person has acquired and automated due to the memory process. It is typically used unconsciously. In general, this includes stereotypes, habits, cognitive schemes, 
etc. When taking the test, a person must suppress learned and automated knowledge and concentrate his attention on others, known as inhibitory control (Gregor 2014; McLoad 1991).

In direct relation to the Stroop test, we can say that there is a conflict between the motivational strength of the instructions and reading the colour in which the colour is written and the automaticity of reading the meaning of the word. Sensory stress is then characterised as a conflict between the requirements placed on the person and the tendencies or possibilities of adequately reconciling these requirements (Kulišt'ák 2003). In addition to those already mentioned cognitive abilities, performance in the Stroop test also reflects the quality of psychomotor tempo and resistance to sensory stress.

In terms of developmental psychology, during adolescence changes also take place in selected cognitive abilities - memory and attention. An adolescent can better control his attention, apply various strategies to better focus, and easier maintain his attention. Selective attention (selection of stimulus) is also improved, as is its distribution (the ability to divide attention between stimuli). Attention achieves higher effectiveness (Vágnerová 2005; Weiner et al. 2003).

\section{Methods}

The study group consisted of 32 adolescents aged $18 \pm 2.4$ years. All the probands are registered members of the Slovak Judo Federation. The requirement for acceptance into the study group was active participation in judo for a period of at least 3 years prior to the start of the study.

We obtained the rankings of the probands from the website of Judo klub Slávia STU (www.judostu.sk), where the rankings of all its members can be found.

\section{Test of cognitive abilities}

To assess the level of selected cognitive abilities, we used the Stroop Color-Word Test - Victoria version (VST), which measures the executive functions of the brain and is commonly used for neuropsychological assessment. VST is used to test selective attention and processing speeds (Bayard, Erkes \& Moroni 2011).

The VST consists of three templates measuring $21.5 \times 14 \mathrm{~cm}$, each containing six rows of four items. There is a $1 \mathrm{~cm}$ space between the rows. In the first part, T, the subjects must name colours as quickly as they can (24 dots printed in blue, green, red and yellow). Each colour is used six times and they are placed in a pseudorandom order into a pattern where they appear only once in the row. In the second part, S, the dots are replaced by neutral words 
(when, or, but, over) printed in small letters. The subject must say the colour in which each word is printed regardless of the word itself. In the third part, B, the colour words 'blue, green, red, and yellow' are printed in small letters where the colour of the word is not the same as the named colour. In the Victoria version, the templates are always presented in the same T, S, B order. The subject is instructed to read or name the colour as fast as they can. Timing starts immediately after the instructions are given. The times and age of each proband were recorded into a log.

\section{Methods used to assess interpretation of the results}

The data were processed and assessed using basic mathematical and statistical methods of qualitative and quantitative research.

The Pearson correlation coefficient (r) determines the degree of dependence between two variables. The correlation coefficient presents limited possibilities of interpretation. In our study, we were not looking for a causal relationship but rather an associative relationship between the individual variables.

The values of the correlation coefficient of the variables were differentiated by the degree of direct correlation $(+1)$ and the degree of indirect correlation (-1). Our interpretation of the associative relationships according to the correlation coefficient is based on logical analysis of the strength of the relationship between the variables.

The statistical significance, calculated using IBM SPSS Statistics 23, is assessed at a level of statistical significance of $1 \%(\mathrm{p}<0.01)$ and $5 \%(\mathrm{p}<0.05)$.

\section{Results and discussion}

The output of the relational analysis using Pearson Correlation between variables is contained in the Correlation Matrix (Table 1).

\section{Table 1}

Correlation Matrix

\begin{tabular}{|c|c|c|c|c|c|}
\hline & age & $T$ (dots) & S (words) & B (colours) & ranking \\
\hline age & 1,000 & $-.730 * *$ & $-.727 * *$ & $-.714 * *$ & .482 \\
\hline T (dots) & $-.730 * *$ & 1.000 & $.764 * *$ & .456 & -.407 \\
\hline S (words) & $-.727 * *$ & $.764 * *$ & 1.000 & .493 & -.291 \\
\hline B (colours) & $-.714 * *$ & .456 & .493 & 1.000 & -.246 \\
\hline ranking & .482 & -.407 & -.291 & -.246 & 1.000 \\
\hline
\end{tabular}


We can see numerous associative relationships in the correlation coefficients of variables in the correlation matrix. Our study did not endeavour to assess the associative relationships between the individual categories (T, S, B) of the Stroop test.

The strongest associative relationship of indirect correlation at the $1 \%$ level of statistical significance is found between age and the individual categories of the Stroop test (T, S, B). This is an indirect correlation, so the higher the age of the proband, the lower the time (better performance) the proband achieved in the Stroop test. It is necessary to add that the most significant changes in cognitive abilities are seen in adolescence (Weiner et al. 2003). Vágnerová (2005) adds that an adolescent can better control his attention, apply various strategies to easier focus, and maintain his attention. Selective attention is also improved, as is the ability to divide attention. These changes are related to changes in neurophysiological development. Langmeier \& Krejčírová (2006) state that construction of the brain is practically finished by this period, but the activity of the brain core improves. We can say that this period is the peak of a human's cognitive abilities.

According to the descriptive characteristic, we can express the strength of the association between ranking and category $\mathrm{T}($ dots $)$ as average $(\mathrm{r}=-.407)$. The associative relationship between the rankings of probands in categories S (words) and B (colours) is weak $(\mathrm{r}=-.291 ; \mathrm{r}=-.246)$. All the presented associative relationships between rankings and performance in the individual categories of the Stroop test are those of indirect correlation.

According to our findings we can assume, that cognitive ability- selective attention is not apply in performance in judo to a degree that we can say ranking of judokas depends on chosen cognitive abilities, which are measured by Stroop test.

Any of the available studies, did not look to the correlation between attention and the rankings in judo, but we can see the importance of attention for performance in judo through some similar studies. For example, about importance of selective attention for performance in judo say Rashka and Mangold (2005) as well. Moreover, in their study they advert, that selective attention measured by Stroop test was improved by the alarm reaction before and after choking. Research results Mihailescu \& Sava (2013) also showed that success or failure of specific technical and tactical actions in competitive judo are influenced by the focus and attention.

We can see different results of researches in area of attention investigation. The reasons of difference in results in importance of attention for performance judo can be various. 
Results of studies presented that expert athletes have shown better performance than beginners have on cognitive tests (Fontani \& Lodi 2002; Hack, Memmert \& Rupp 2009; Hamon \& Seri 1989; Radlo, Janelle, Barba \& Frehlich 2001; Taliep et al. 2008). In context of these results we can think, judokas in our group are in terms of performance below the world standard and generally, they are at a lower level in all aspects of sport performance, also in the context of cognitive abilities, especially attention. The second suggestion for improvement of research this scientific field can by change of research tool.

Strength of relationship between performance in the individual Stroop categories and the ranking of the judokas is not statistically significant, so the determination is that the level of selected cognitive abilities in the study group does not correlate with ranking. Therefore, chosen cognitive abilities measured by Stroop test are not limiting factor for success in judokas ranking.

\section{Conclusions}

Research into the psychological characteristics of judokas is not common in sport psychology. This paper presents the findings of associative relationships between the level of selected cognitive abilities, age, and the level of athletic performance in judo according to ranking. We see a statistically significant correlation coefficient between all the categories $(\mathrm{T}$, S, B) of the Stroop test and the age of the probands. According to the descriptive characteristic, the correlation between age and the level of selected cognitive abilities of the study group is strong. The associative relationship of indirect correlation between age and the level of selected cognitive abilities is expressed as the $1 \%$ level of statistical significance, and the correlation coefficient values are below -0.7 .

Based on the correlation coefficients, we can conclude that there is indirect correlation between the level of selected cognitive abilities and the athletic performance of judokas according to ranking, but it is without statistical significance.

Our paper presented research outcomes that may serve as a quality source of information for further research on cognitive abilities.

\section{Acknowledgements}

This study was supported through a Scientific Grant Agency of the Ministry of Education of Slovak Republic Vega 1/0690/14 


\section{References}

1. BAYARD, S., J. ERKES \& CH. MORONI et al., 2011. Victoria Stroop Test. In: Archives of Clinical neuropsychology [online]. Jún 2011, [cit. 2015-01-22]. Oxford: Oxford University Press. Dostupné z: http://acn.oxfordjournals.org/content/early/2011/08/26/arclin.acr053

2. FONTANI, G. \& L. LODI, 2002. Reactivity and event-related potentials in attentional tests: Effect of training. Perceptual and Motor Skills. 94, pp. 817-833.

3. HACK, J., MEMMERT, D. \& A. RUPP, 2009. Attentional mechanisms in sports via brain-electrical event-related potentials. Research Quar-terly for Exercise \& Sport. 80, pp. 727-738.

4. HAMON, J. F. \& B. SERI, 1989. Cortical reactivity during reaction time tests in sprinters. Clinical Neurophysiology. 19, pp. 109-122.

5. KULIŠŤÁK, P. 2003. Neuropsychologie. Praha: Portál. ISBN 80-7178-554-7.

6. LANGMEIER, J. \& D. KREJČIŘOVÁ, 2006. Vývojová psychologie. Praha: Grada Publishing. ISBN 80-247-1284-9.

7. Mc LOAD, C. M., 1991. Half a Century of Research on the Stroop effect: An Integrative Review. Psychological Bulletin. 109(2), pp. 163-203.

8. MIHAILESCU, L \& M. A. SAVA, 2013. The role of attention in the achievement of sport performance in judo. Procedia - Social and Behavioral Sciences, 3rd World Conference on Psychology, Counselling and Guidance. pp. 1242-1249.

9. MORAVEC, R. et al., 2007. Teória a didaktika výkonnostného a vrcholového športu. Bratislava: FTVŠ UK, Slovenská vedecká spoločnost' pre telesnú výchovu a šport.

10. MOSTAFA, I., 2009. Mental processes and their relationship to Tactical behavior for judo player. Search within the requirements for the degree of Doctor of Philosophy in Physical Education E 1430 - 2009. Benha University: Faculty of physical education.

11. RADLO, S. J., C.M. JANELLE, D.A. BARBA \& C.G. FREHLICH, 2001. Perceptual decision making for baseball pitch recognition: Using P300 latency and amplitude to index attentional processing. Research Quarterly for Exercise and Sport. 72, pp. 22-31.

12. RASHKA, C. \& R. MANGOLD, 2005. Stress-induced changes of attention during choking in judo. Sportverletzung Sportschaden: Organ der Gesellschaft fur OrthopadischTraumatologische Sportmedizin. 19(4), p. 187-190. 
13. SÁNCHEZ- LÓPEZ, J., T. FERNÁNDEZ, J. SILVA-PEREYRA \& J. A. MARTÍNEZMESA, 2013. Differences between Judo, Taekwondo and Kung-fu Athletes in Sustained Attention and Impulse Control. Psychology, 4(7), pp. 607-612.

14. STERNBERG, R. J., K. STERNBERG \& J. MIO, 2012. Cognitive Psychology. Belmont: Wadsworth. ISBN 978-1133313915.

15. ŠTEFANOVSKÝ, M., 2015. Fyziologické, motorické asomatické charakteristiky džudistov z hl’adiska veku aúrovne trénovanosti. Bratislava: Slovenská vedecká spoločnost' pre telesnú výchovu a šport. ISBN 978-80-89075-45-4.

16. TALIEP, M. S., A. S. C. GIBSON, J. GRAY, van der L. MERWE et al., 2008. Eventrelated potentials, reaction time, and response selection of skilled and less-skilled cricket batsmen. Perception. 37, pp. 96-105.

17. VÁGNEROVÁ, M., 2005. Vývojová psychologie I.: Dětství a dospívání. Praha: Karolinum. ISBN 80-246-0956-8.

18. WEINER, I. et al. 2003. Handbook of psychology: Developmental psychology. Hoboken: Willey. ISBN-13: 978-0470768860.

19. ZUBITASHVILI, G. \& K. MAYASHVILI, 2012. Characteristics of attention of young judokas at different ages. Journal of Physical Education and Sport. 12(1), pp. 125-128. 